\title{
The Nd-, Sr- and Pb-isotopic character of lavas from Taal, Laguna de Bay and Arayat volcanoes, southwestern Luzon, Philippines: implications for arc magma petrogenesis
}

\author{
Samuel B. Mukasa a ${ }^{\text {, Martin F.J. Flower }}{ }^{\mathrm{b}}$, Asta Miklius ${ }^{\mathrm{c}}$ \\ ${ }^{a}$ Department of Geological Sciences, University of Michigan, 1006 C.C. Little Building, Ann Arbor, MI 48109-I063, USA \\ ${ }^{b}$ Department of Geological Sciences, University of Illinois, P.O. Box 4348, Chicago, IL 60680, USA \\ ${ }^{c}$ U.S. Geological Survey, Hawaiian Volcano Observatory, P.O. Box 51, Hawaii National Park, HI 96718, USA
}

(Accepted 18 November 1993)

\begin{abstract}
Following the amalgamation of a collage of pre-Neogene terranes largely by strike-slip and convergence mechanisms to form the Philippine islands, volcanic chains, related to oppositely dipping subduction zones, developed along the eastern and western margins of the archipelago. There is ample field evidence that this volcanic activity, predominantly calc-alkaline in chemical character, had commenced by the Oligocene.

Volcanoes resulting from subduction along the Manila-Negros trench in the west (e.g., Taal, Laguna de Bay and Arayat) form a high-angle linear array, trending away from the MORB field on Pb-isotopic covariation diagrams; have the highest $\mathrm{Sr}$ - and lowest Nd-isntopic compositions, of the two chains (but nevertheless plotting above bulk earth on the ${ }^{87} \mathrm{Sr} /{ }^{86} \mathrm{Sr}$ versus ${ }^{143} \mathrm{Nd} /{ }^{144} \mathrm{Nd}$ covariation diagram); and exhibit $\mathrm{Sm} / \mathrm{Nd}$ and $\mathrm{Rb} / \mathrm{Sr}$ values that are lower and higher, respectively, than the estimated values for bulk earth. While the $\mathrm{Sm} / \mathrm{Nd}$ and $\mathrm{Rb} / \mathrm{Sr}$ characteristics are common to both chains, volcanoes associated with the Philippine-East Luzon trench have $\mathrm{Pb}$-isotopic compositions that fall in the Indian Ocean MORB field and that require time-integrated evolution in a high Th/U environment. They also have higher $\mathrm{Nd}$ - and lower $\mathrm{Sr}$-isotopic ratios.

The source materials of Philippine volcanoes, therefore, have undergone varied recent enrichments in LILE, as indicated by the decoupling of isotopic and elemental ratios. These enrichments, particularly for the western volcanoes, cannot be entirely due to small degrees of partial melting in the mantle wedge, considering that they were accompanied by elevations in radiogenic $\mathrm{Pb}$. Elevated $\mathrm{Pb}$ ratios are best explained by the introduction of subducted, continentally derived sediments. The sedimentary component in the western volcanoes is probably the South China Sea sediments derived largely from Eurasia. That this component is not available in the Philippine-East Luzon trench is reflected by the fact that the eastern volcanoes have higher Nd- and lower Sr-isotopic ratios as well as less radiogenic common $\mathrm{Pb}$.
\end{abstract}

\section{Introduction}

The Taal volcanic center, situated within a caldera/volcano-tectonic depression, is a promi- nent Neogene feature located in southwestern Luzon, Philippines (Fig. 1). Of the volcanic complexes lining the western margin of Luzon, Taal and a few others in its vicinity (e.g., Banahaw, 
Laguna de Bay and San Cristobal) have the most controversial and perhaps least understood tectonic settings. According to Cardwell et al. (1980) and Hamburger et al. (1983), this group of volcanoes is the product of eastward-dipping subduction along the Manila trench, like other volcanoes along western Luzon. Divis (1980), Cruz and Umbal (1983) and Wolfe and Self (1983), however, have shown that, although subduction might have been important in their development, Taal and its neighbors occupy an area that has been affected by deep-seated and regionally important cross faults. Implicit in this observation is that the composition and processes controlling the generation of magmas in the Taal region probably evolved with the changing stress regimes. Indeed, recent isotopic studies of volcanic materials from the area have shown that there are fundamental differences in source character between Neogene southwestern Luzon volcanoes and contempora-

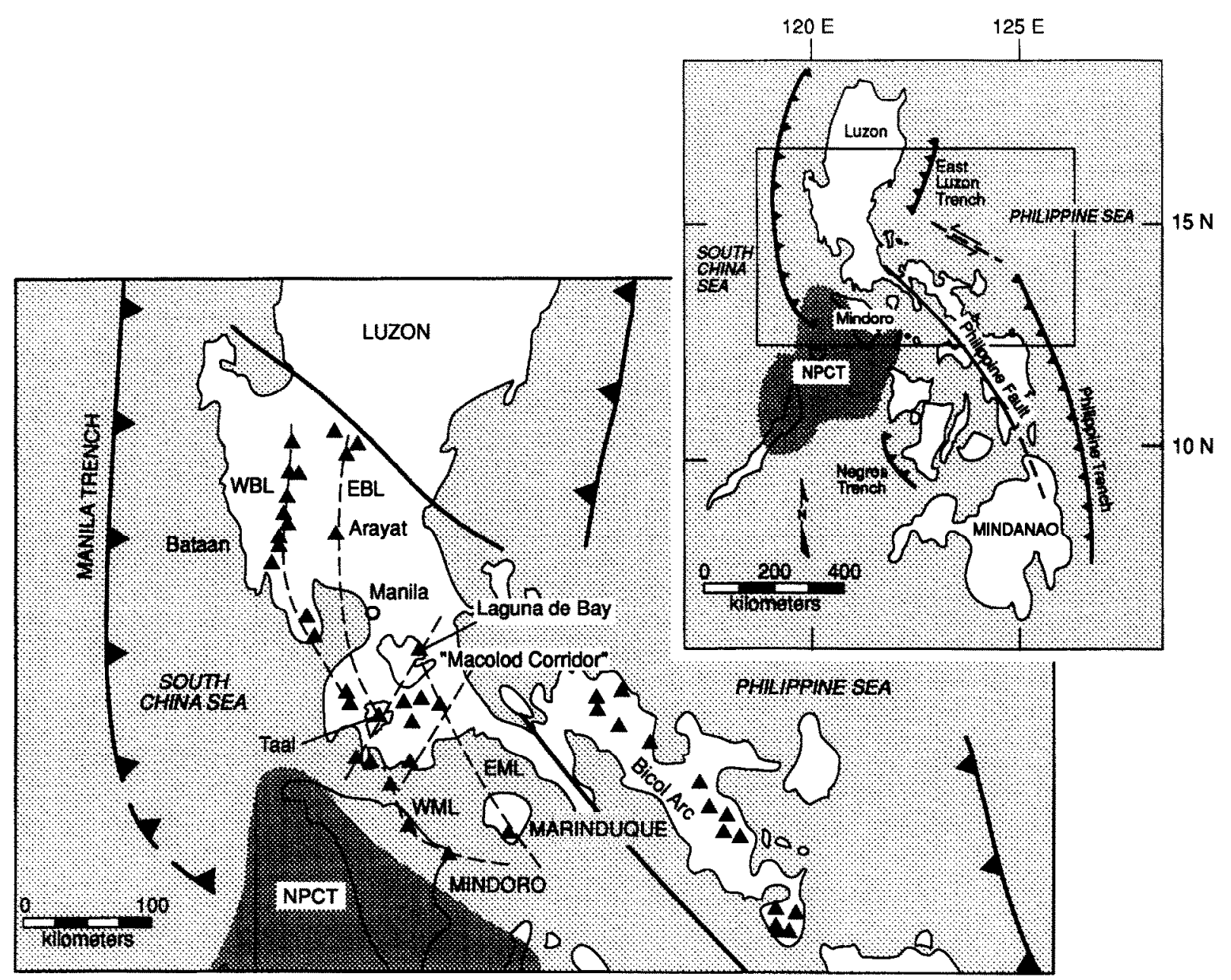

Fig. 1. Generalized tectonic map of the northern Philippine islands showing the locations of the Taal, Laguna de Bay and Arayat volcanic complexes, as well as the oppositely dipping subduction zones; the North Palawan Continental Terrane (NCFT); the various volcanic lineaments $(E B L=$ East Bataan Lineament; $W B L=$ West Bataan Lineament; $E M L=$ East Mindoro Lineament; and $W M L=$ West Mindoro Lineament), the Philippine transform fault, and the Macolod Corridor. The insert shows the entire archipelago, and a box in the middle of it outlines the area of the main map. 
neous volcanoes in the same chain to the north (Mukasa et al., 1987; Defant et al., 1988; Knittel et al., 1988).

Emergence of the cross faults and the spatially related lavas of the Taal group-with higher $\mathrm{K}_{2} \mathrm{O}$ and incompatible element concentrations as well as more radiogenic isotopic ratios-appears to have coincided with collision in the late Miocene between the Philippine archipelago and the North Palawan Continental Terrane (NPCT). Mukasa et al. (1987), Defant et al. (1988) and Knittel et al. (1988) have therefore concluded, on the basis of isotopic and major and trace element compositions as fingerprints, that introduction of crustal materials from the NPCT to the subduction zone (either slivers of continental crust or terrigenous sediments on the leading edge of the terrane), contributed to the sourcc character of post-collision lavas erupted between southwestern Luzon and Panay (Fig. 1).

In the light of new isotopic and trace element results on post-spreading lavas scattered throughout the South China Sea Basin (SCSB) (Tu et al., 1991), subcontinental lithosphere, associated with the NPCT and introduced into the segment boundary between the Manila and Negros subduction systems by collision, has to be considered as an alternative source. If post-spreading lavas of the SCSB reflect a lithospheric source, then this source is heterogeneous, enriched in low field strength elements (LFSE) and light rare earth elements (LREE) relative to N-MORB, depleted in ${ }^{87} \mathrm{Sr} /{ }^{86} \mathrm{Sr}$ and ${ }^{143} \mathrm{Nd} /{ }^{144} \mathrm{Nd}$ relative to bulk earth, and similar in its $\mathrm{Pb}$-isotopic signatures to global magma reservoirs, with the Dupal isotopic anomaly as defined by Hart $(1984 ; 1988)$. Defined in terms of $\mathrm{Pb}$-isotopic compositions, the Dupal anomaly is the deviation of any data set from the Northern Hemisphere Reference Lines (NHRL), which pass through the data fields for basalts from the East Pacific Rise, Mid Atlantic Ridge and several ocean islands. The anomaly is expressed as the vertical deviation in ${ }^{207} \mathrm{~Pb} /{ }^{204} \mathrm{~Pb}$ or ${ }^{208} \mathrm{~Pb} /{ }^{204} \mathrm{~Pb}$ from the line, with the minimum deviation limit having been set at a $\Delta 208 / 204$ of +60 by Hart (1988). Many (but not all) of the SCSB geochemical features are shared by the lavas from Taal Volcano, lending impetus for a comparative assessment of rocks from the two areas. Samples from two additional volcanoes in southwestern Luzon are evaluated for reference: the Laguna de Bay volcanic complex, which has the same general tectonic setting as Taal Volcano but is possibly older, and Arayat Volcano, a K-rich member of the western Luzon chain of volcanoes, but distant from any possible cross-faulting effects.

\section{Regional tectonic setting}

The pre-Neogene geology of the Philippine archipelago is dominated by a collage of arc, continental and ophiolitic blocks that, on the basis of structural, paleontological, stratigraphic and paleomagnetic data, are believed to have formed separately under different stress regimes far from their present geographic locations (Hsü, 1972; Hamilton, 1979; De Boer et al., 1980; Balce et al., 1981; Hashimoto, 1981; Fuller et al., 1983; Karig, 1983; McCabe et al., 1985; Karig et al., 1986). Following amalgamation of these terranes by strike-slip and convergence mechanisms, volcanic chains, related to oppositely dipping subduction zones, developed along the eastern and western margins of the archipelago. Volcanic activity, associated with the eastward subduction of South China Sea crust along the Manila-Negros trench and the westward subduction of the Philippine Sea plate along the Philippine-East Luzon trench (Bicol sector), has constructed two subparallel belts of predominantly calc-alkaline stratovolcanoes since the Oligocene (Hsü, 1972; Hamilton, 1979; De Boer et al., 1980; Balce et al., 1981; Hashimoto, 1981; Fuller et al., 1983; Karig, 1983; McCabe et al., 1985; Karig et al., 1986). Taal, Laguna de Bay and Arayat, which are compared here, occur in the central sector of the western volcanic belt in the southwest of Luzon island, in association with eastward subduction along the Manila-Negros trench (Fig. 1).

Neogene volcanic chains along the western Philippines have been referred to as the West Philippine arc (Mukasa et al., 1987), the Bataan and Mindoro arcs (De Boer et al., 1980; Defant et al., 1988) and the Luzon arc (Defant et al., 
1989); all of these names remain in use at prescnt. These volcanoes form two closely spaced, subparallel chains that Defant et al. (1988) have termed the eastern and western Bataan lineaments (EBL and WBL), in northern and central Luzon, and eastern and western Mindoro lineaments (EML and WML) in southwestern Luzon, Mindoro and Marinduque. The Bataan and Mindoro lineaments are separated by a zone of northeast-trending cross-faults which define a rift-like tectonic feature, referred to by Defant et al. (1988) and Förster et al. (1990) as the Macolod Corridor (MC). Taal and Laguna de Bay are located in this feature, while Arayat is part of the
EBL. Defant et al. (1988) have pointed out, however, that Laguna de Bay and Taal's oldest eruptive products might be older than the $\mathrm{MC}$ and should, therefore, not display cross-fault effects, if these are distinct and are reflected by the lava chemistry. Depth to the top of the subducted slab beneath EBL and MC volcanoes is another important distinction, possibly bearing on composition of the magmas. Seismic studies by Cardwell et al. (1980), Hamburger et al. (1983), Hayes and Lewis (1984) and Rangin et al. (1988) have revealed that the top of the subducted slab is 180 $200 \mathrm{~km}$ beneath Arayat, but much deeper beneath the MC volcanoes.

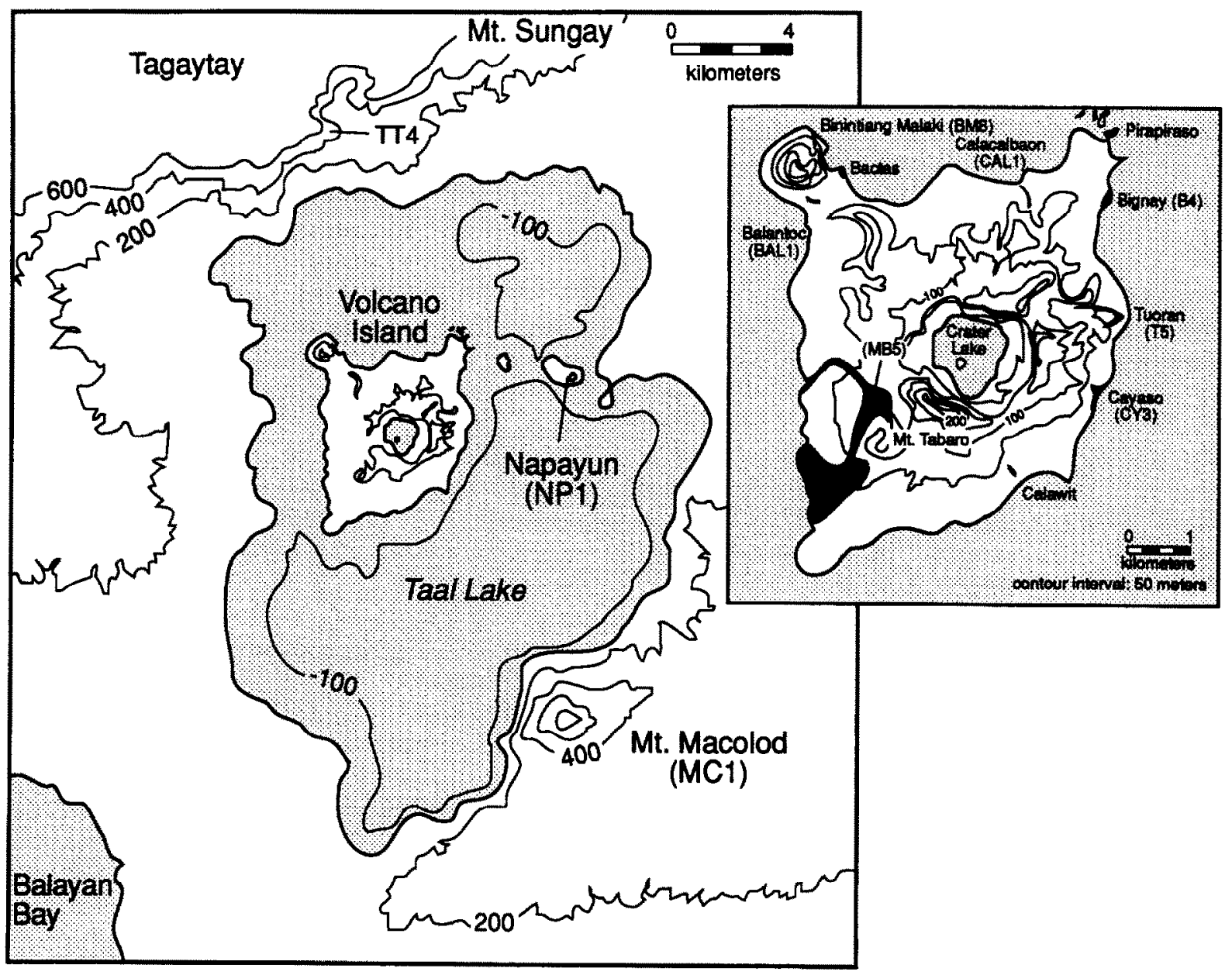

Fig. 2. Map of Taal Volcano, showing the locations of the caldera rim samples at Tagaytay, Napayun Island and Mt. Macolod. The insert is an enlargement of Volcano Island and shows the lava flows sampled for this study. 
Immediately west of the Manila-Negros trench system is the South China Sea Basin (SCSB), a marginal basin which began to develop in the Paleocene, along what was originally an Andeantype convergence zone, and evolved through crustal stretching and sea-floor spreading (Taylor and Hayes, 1983; Ru and Piggott, 1986; Tapponnier et al., 1986). Remnant crustal blocks separated from Eurasia by the marginal basin opening are presently scattered throughout the basin, but are conccntrated along the eastern margin where they collided with Borneo and the Philippine archipelago, effectively terminating spreading. The NPCT, which abuts islands in the western central Philippines (Fig. 1), and appears to have contaminated post-collision magma sources in the area, is one of these crustal blocks.

After termination of spreading in the SCSB, widespread volcanism penetrated the basin floor, stranded microcontinents and the mainland, from Thailand in the south to Korea in the north. Tu et al. (1991) have argued that these post-spreading lavas probably sampled the subcontinental lithosphere - dispersed with basin opening - that had been enriched along the, now defunct, Andean-type margin of Southeast Asia. It is worth considering and investigating the possibility that such a lithospheric source was introduced into the $\mathrm{MC}$ region with collision between the NPCT and the Philippine archipelago.

\section{Previous geochemical studies of Taal Volcano and South China Sea Basin basalts}

Geochemical studies by Miklius et al. (1991) of Taal lavas have revealed that calc-alkaline and tholeiitic magmas evolved coevally. On Volcano Island, the medial post-caldera edifice of cones and tuff rings of the complex (Fig. 2), the two lava suites are easily distinguished from one another, and from pre-caldera eruptive products rimming Taal Lake, on the basis of major elements and incompatible trace element ratios. For the equivalent $\mathrm{MgO}$ content, post-caldera lavas on Volcano Island have higher incompatible element contents than pre- and syn-caldera collapse lavas at Mt. Macolod and Napayun Island (loca- tions in Fig. 2). The differences between calc-alkaline and tholeiitic suites on Volcano Island are best explained by their evolution in separate systems without material exchange between the two rock series. Chemical and petrographic evidence suggest that fractional crystallization and mixing between less- and more-evolved magmas were important processes in development of both series, with mixing predominating in the calc-alkaline suite.

Compared to the WBL volcanoes, Taal lavas (and lavas of the other EBL and MC volcanoes) are more alkalic and have higher contents of incompatible elements (Miklius et al., 1991). Defant et al. (1988) attribute these features to very small degrees of partial melting as compared to WBL lavas, which have lower contents of these elements. Contradiction between certain trace element ratio covariations (e.g., $\mathrm{Ba} / \mathrm{Y}$ versus $\mathrm{Zr} / \mathrm{Y}$ ) and incompatible element contents, with respect to degrees of partial melting, have led Miklius et al. (1991) to conclude that source heterogeneity was the principal factor determining parent melt differences.

In their comprehensive study of post-spreading lavas in the SCSB region, Tu et al. (1991) observed LFSE and REE enrichments relative to $\mathrm{N}-\mathrm{MORB}$, as well as ${ }^{87} \mathrm{Sr} /{ }^{86} \mathrm{Sr}$ and ${ }^{143} \mathrm{Nd} /{ }^{144} \mathrm{Nd}$ ratios that are variable but are depleted relative to bulk earth values. In addition, they discovered not only heterogeneities in isotopic and trace element ratios, but a decoupling of the two parameters. The observed decoupling is best explained in terms of recent but protracted enrichment histories, of the type believed to occur in supra-subduction zone mantle wedge environments. $\mathrm{Pb}$-isotopic compositions for most of the lavas fall in the fields for the Dupal isotopic anomaly $(\Delta 208 / 204=45-73)$, implying that either the anomaly, documented chiefly in the southern hemisphere (Hart, 1984; 1988), extends into this region, or that the SCSB source is a relatively isolated domain produced by local enrichment processes. Dupal-type Pb-isotopic compositions have also been documented on samples from the Philippine Sea by Hickey-Vargas (1991), and from further north, in the Sea of Japan, by Tatsumoto and Nakamura (1991). 


\section{Sampling}

The Taal samples used in this study, for which locations are shown in Fig. 2, are a sub-set of the much larger suite studied and described in detail by Miklius et al. (1991); descriptions here are therefore brief. A representative compositional spectrum and broad time sequences were the principal criteria used to choose a sample sub-set. Thus basalt, basaltic andesite, andesite and dacite, ranging in relative age from pre-caldera to historic post-caldera collapse, have been analyzed. The presence of multiple vents has produced complex stratigraphic relations, requiring tight isotopic age constraints, as yet unavailable. In the present study time resolution is limited to pre-, syn- and post-caldera collapse, which is nevertheless instructive. The oldest samples come from Mt. Macolod, a deeply eroded satellite plug, and from pre-caldera bombs at the northwestern rim of the volcanic center. Lavas of the 1969 eruption of Mt. Tabaro on Volcano Island, a post-caldera edifice, constitute the youngest group of samples. No relative time constraints have been attached to the Laguna de Bay and Arayat samples, all of them basaltic, since they are so few in number.

\section{Analytical procedures}

Whole-rock powders were leached with warm $2 N \mathrm{HCl}$ and $3 \mathrm{~N} \mathrm{HNO}_{3}$ sequentially, and then washed with doubly distilled $\mathrm{H}_{2} \mathrm{O}$. Samples of approximately $100 \mathrm{mg}$ for $\mathrm{Pb}$ and $50 \mathrm{mg}$ for $\mathrm{Rb}-\mathrm{Sr}$ and $\mathrm{Sm}-\mathrm{Nd}$ were dissolved in a 10:1 solution of $\mathrm{HF}: \mathrm{HNO}_{3}$, with $14 \mathrm{~N} \mathrm{HNO}_{3}$ added first to minimize the formation of fluorides. The dissolutions were carried out in screw-top PFA Teflon beakers on a hot plate set at $150^{\circ} \mathrm{C}$.

$\mathrm{Pb}$ was isolated using $\mathrm{AG} 1 \mathrm{X8}$ anion resin on $0.5 \mathrm{ml}$ and $0.2 \mathrm{ml} \mathrm{HBr}-\mathrm{HCl}$ ion exchange columns. A procedural blank run with the sam-

Table 1

Elemental concentrations and isotopic compositions for lavas from Taal, Laguna de Bay and Arayat volcanoes, Luzon Island, Philippines

\begin{tabular}{|c|c|c|c|c|c|c|c|c|c|c|c|c|}
\hline \multirow[t]{2}{*}{ Sample } & \multicolumn{5}{|c|}{ Concentrations (ppm) ${ }^{a}$} & \multicolumn{7}{|c|}{ Isotopic Ratios $^{b}$} \\
\hline & $\mathbf{R b}$ & $\mathrm{Sr}$ & $\mathrm{Sm}$ & $\mathrm{Nd}$ & $\begin{array}{l}\text { Th/ } \\
\mathrm{Ta}\end{array}$ & $\begin{array}{l}{ }^{87} \mathrm{Rb} / \\
{ }^{86} \mathrm{Sr}\end{array}$ & ${ }^{87} \mathrm{Sr} /{ }^{86} \mathrm{Sr}$ & $\begin{array}{l}{ }^{147} \mathrm{Sm} / \\
{ }^{144} \mathrm{Nd}\end{array}$ & $\begin{array}{l}{ }^{143} \mathrm{Nd} / \\
{ }^{144} \mathrm{Nd}\end{array}$ & $\begin{array}{l}{ }^{206} \mathrm{~Pb} / \\
{ }^{204} \mathrm{~Pb}\end{array}$ & $\begin{array}{l}{ }^{207} \mathrm{~Pb} / \\
{ }^{204} \mathrm{~Pb}\end{array}$ & $\begin{array}{l}{ }^{203} \mathrm{~Pb} / \\
{ }^{204} \mathrm{~Pb}\end{array}$ \\
\hline \multicolumn{13}{|c|}{ Taal Volcano } \\
\hline B4 & 26 & 385.6 & 2.83 & 11.77 & 23.1 & 0.195 & $0.70457 \pm 2$ & 0.145 & $0.51281 \pm 2$ & 18.581 & 15.614 & 38.729 \\
\hline BAL1 & 86 & 211.9 & 4.01 & 18.76 & 29.9 & 1.175 & $0.70459 \pm 4$ & 0.129 & $0.51281 \pm 2$ & 18.577 & 15.584 & 38.626 \\
\hline BM8 & 81 & 237.5 & 4.30 & 19.91 & 28.6 & 0.987 & $0.70458 \pm 4$ & 0.130 & $0.51283 \pm 2$ & 18.635 & 15.656 & 38.846 \\
\hline CAL1 & 28 & 355.6 & 2.99 & 12.41 & 20.5 & 0.228 & $0.70452 \pm 4$ & 0.145 & - & 18.554 & 15.586 & 38.647 \\
\hline CY3 & 32 & 328.2 & 3.20 & 13.60 & 24.5 & 0.282 & $0.70458 \pm 2$ & 0.142 & - & 18.585 & 15.599 & 38.687 \\
\hline MB5 & 26 & 345.5 & 2.97 & 12.11 & 18.5 & 0.218 & $0.70454 \pm 2$ & 0.147 & $0.51282 \pm 2$ & 18.639 & 15.668 & 38.867 \\
\hline MC1 & 23 & 344.5 & 3.19 & 12.06 & 14.8 & 0.193 & $0.70443 \pm 4$ & 0.159 & $0.51284 \pm 4$ & 18.570 & 15.610 & 38.675 \\
\hline NP1 & 47 & 358.5 & 4.03 & 17.58 & 24.5 & 0.380 & $0.70454 \pm 2$ & 0.138 & $0.51279 \pm 2$ & 18.593 & 15.620 & 38.743 \\
\hline T5.5 & 29 & 328.4 & 3.20 & 12.96 & - & - & $0.70449 \pm 2$ & 0.149 & $0.51285 \pm 2$ & 18.567 & 15.591 & 38.652 \\
\hline TT4 & 50 & 378.6 & 4.02 & 17.14 & 26.7 & 0.382 & $0.70472 \pm 2$ & 0.141 & $0.51281 \pm 2$ & 18.623 & 15.643 & 38.803 \\
\hline \multicolumn{13}{|c|}{ Laguna De Bay Volcano } \\
\hline LBMI-1 & - & - & 6.44 & 29.32 & - & - & $0.70426 \pm 4$ & 0.132 & $0.51276 \pm 2$ & - & - & - \\
\hline LIN-2 & - & - & 6.59 & 29.88 & - & - & $0.70409 \pm 2$ & 0.133 & $0.51285 \pm 2$ & 18.621 & 15.594 & 38.605 \\
\hline TLHI-9 & - & 413.0 & 3.90 & 15.96 & - & - & $0.70426 \pm 2$ & 0.147 & $0.51285 \pm 2$ & 18.473 & 15.552 & 38.456 \\
\hline \multicolumn{13}{|c|}{ Arayat Volcano } \\
\hline EG80-89 & - & 446.9 & 4.01 & 16.37 & - & - & $0.70410 \pm 4$ & 0.148 & $0.51287 \pm 2$ & 18.473 & 15.584 & 38.604 \\
\hline EG80-90 & - & 480.3 & 5.59 & 27.42 & - & - & $0.70432 \pm 2$ & 0.123 & $0.51281 \pm 2$ & 18.505 & 15.605 & 38.695 \\
\hline
\end{tabular}

\footnotetext{
${ }^{2} \mathrm{Rb}$ concentrations determined by XRF; Th and Ta by $\mathrm{NAA}$; and $\mathrm{Sr}, \mathrm{Sm}$ and $\mathrm{Nd}$ by isotope dilution.

${ }^{b}$ Errors on the ${ }^{87} \mathrm{Sr} /{ }^{86} \mathrm{Sr}$ and ${ }^{143} \mathrm{Nd} /{ }^{144} \mathrm{Nd}$ values represent $2 \sigma_{\mathrm{m}}$ based on within-run statistics. Errors for the Pb ratios are smaller than $0.1 \%$. Normalization values are given in the analytical techniques section.
} 
ples had $0.7 \mathrm{ng}$ of $\mathrm{Pb}$, a small amount $(<1 \%)$ of the total $\mathrm{Pb}$ in each sample. The $\mathrm{Pb}$ samples were loaded on rhenium single filaments using the phosphoric acid-silica gel method.

Sample aliquots dissolved for $\mathrm{Rb}-\mathrm{Sr}$ and $\mathrm{Sm}-$ $\mathrm{Nd}$ isotopic measurements were dried down and redissolved three times in $6 \mathrm{~N} \mathrm{HCl}$, and finally equilibrated in $2.5 \mathrm{~N} \mathrm{HCl}$ to be loaded onto columns. Rb and Sr were separated from other elements and from each other using $2.5 \mathrm{~N} \mathrm{HCl}$ on cation exchange columns; REE concentrates were removed from the same columns using $6 \mathrm{~N}$ $\mathrm{HCl}$. The REE fractions were dried and then picked up in $0.25 \mathrm{~N} \mathrm{HCl}$ for introduction onto columns tightly packed with Bis (2-ethylhexyl) hydrogen phosphate-coated Teflon powder. Tight packing prevented solution channelling that might cause incomplete separation of the REE; a substantial hydrostatic head helped to speed up the flow rate. $\mathrm{Nd}$ was recovered with $0.25 \mathrm{~N} \mathrm{HCl}$, and $\mathrm{Sm}$ with $0.6 \mathrm{~N} \mathrm{HCl}$. Procedural blanks for $\mathrm{Nd}$ and $\mathrm{Sr}$ were $0.04 \mathrm{ng}$ and $0.1 \mathrm{ng}$, respectively.

$\mathrm{Rb}$ samples were loaded on tantalum single filaments with $1 \mathrm{~N} \mathrm{HCl}, \mathrm{Sr}$ on rhenium single filaments with a $\mathrm{TaCl}_{5}$ solution, and $\mathrm{Sm}$ and $\mathrm{Nd}$ on rhenium triple filaments with weak phosphoric acid. $\mathrm{Pb}, \mathrm{Nd}, \mathrm{Sm}$ and $\mathrm{Rb}$ were measured in single-collector mode and $\mathrm{Sr}$ multi-dynamically using a VG Isomass 354 triple collector, thermal ionization mass spectrometer.

Within-run precisions for the measured $\mathrm{Pb}$ ratios were better than $0.05 \%$ at the $95 \%$ confidence level. These ratios have been corrected for fractionation during ionization using replicate analyses of the standard SRM-981 using a factor of $0.09 \pm 0.02 \%$ per atomic mass unit. $\mathrm{Sr}$ and $\mathrm{Nd}$ isotopic fractionations were corrected by normalizing to ${ }^{86} \mathrm{Sr} /{ }^{88} \mathrm{Sr}$ and ${ }^{146} \mathrm{Nd} /{ }^{144} \mathrm{Nd}$ values of 0.11940 and 0.72190 , respectively. The ${ }^{87} \mathrm{Sr} /{ }^{86} \mathrm{Sr}$ value for NBS standard SRM-987, based on replicate analyses, is $0.71024 \pm 1$ and the ${ }^{143} \mathrm{Nd} /{ }^{144} \mathrm{Nd}$ value for the La Jolla standard is $0.51185 \pm 1$.

\section{Results}

Isotopic compositions, and elemental concentrations and ratios, are presented in Table 1 and plotted on various correlation diagrams in Figs. 3-8. Detailed eruption chronologies for Taal, La-

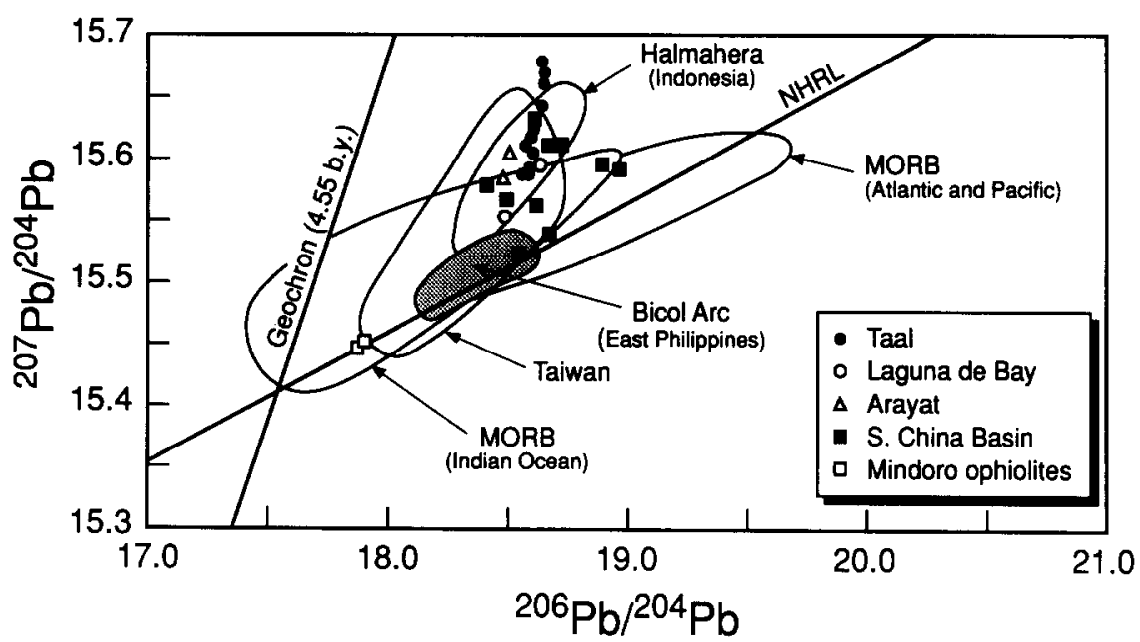

Fig. 3. ${ }^{207} \mathrm{~Pb} /{ }^{204} \mathrm{~Pb}$ versus ${ }^{206} \mathrm{~Pb} /{ }^{204} \mathrm{~Pb}$ covariation diagram with data for Taal, Laguna de Bay and Arayat volcanoes as well as data from Tu et al. (1991, and unpublished) for lavas from Mindoro ophiolites and post-spreading eruptions in the South China Sea Basin. Fields for the Bicol (eastern Philippines), Halmahera (Indonesia) and Taiwanese arcs, and Atlantic, Pacific and Indian Ocean MORB (see references in the text) are included for comparison. Note that the three Philippine volcanoes studied yield a linear array at a high angle to the MORB trend and are more radiogenic than the volcanoes in the Bicol arc of the eastern Philippines. 
guna de Bay and Arayat are still not understood well enough for complete assessments of the time-integrated isotopic record of the magma supply systems. It should be noted, however, that, at Taal, isotopic ratios do not vary as a function of rock composition, distance from the trench, proximity to the cross-faults, or relative age in the pre-, syn- and post-caldera collapse groupings.

\subsection{Pb-isotopic variations}

The Pb-isotopic data for Taal, Laguna de Bay and Arayat volcanoes listed in Table 1 are plotted on ${ }^{207} \mathrm{~Pb} /{ }^{204} \mathrm{~Pb}$ versus ${ }^{206} \mathrm{~Pb} /{ }^{204} \mathrm{~Pb}$ and ${ }^{208} \mathrm{~Pb} /$ ${ }^{204} \mathrm{~Pb}$ versus ${ }^{206} \mathrm{~Pb} /{ }^{204} \mathrm{~Pb}$ covariation diagrams in Figs. 3 and 4, respectively. Also shown for comparison are the fields for MORB (Sun et al., 1975; Sun, 1980; Vidal and Clauer, 1981; Cohen and O'Nions, 1982; Dupré and Allègre, 1983; Hamelin et al., 1984, 1986; Hart, 1984; Hamelin and Allègre, 1985), the Halmahera arc (Morris et al., 1983), the Taiwan arc (Sun, 1980) and data points for post-spreading lavas in the South China Sea Basin and ophiolites on Mindoro island ( $\mathrm{Tu}$ et al., 1991). The most striking feature of the Taal data in Fig. 3 is the remarkably high-angle, linear array relative to the MORB trend, lying totally outside the generalized MORB field which includes fields for Indian Ocean MORB and OIB. Line-fitting through the points yields a correlation coefficient of 0.939 , but no meaningful age information. The two Laguna de Bay samples analyzed for $\mathrm{Pb}$-isotopic compositions fall at the low ${ }^{207} \mathrm{~Pb} /{ }^{204} \mathrm{~Pb}$ end of the Taal array, and one of the two samples lies in the MORB field. Arayat data, in contrast, lie slightly to the left of the Taal-Laguna de Bay array, but are close to the MORB field. On the ${ }^{208} \mathrm{~Pb} /{ }^{204} \mathrm{~Pb}$ versus ${ }^{206} \mathrm{~Pb} /$ ${ }^{204} \mathrm{~Pb}$ diagram (Fig. 4), the Taal-Laguna de Bay array is reproduced, albeit without as good a correlation coefficient as on the diagram in Fig. 3. As in Fig. 3, data for Mt. Arayat fall to the low ${ }^{206} \mathrm{~Pb} /{ }^{204} \mathrm{~Pb}$ side of the array. However, data for all three volcanoes fall within the field for Indian Ocean MORB (Hamelin and Allègre, 1985; Hamelin et al., 1986; Mahoney et al., 1989), considerably above Atlantic and Pacific Ocean MORB, and overlap with the fields for the Halmahera and Taiwan arcs.

On a $\Delta^{207} \mathrm{~Pb} /{ }^{204} \mathrm{~Pb}$ versus $\Delta^{208} \mathrm{~Pb} /{ }^{204} \mathrm{~Pb}$ diagram (Fig. 5), which complements the other $\mathrm{Pb}$ covariation plots, the data fall along a broadly

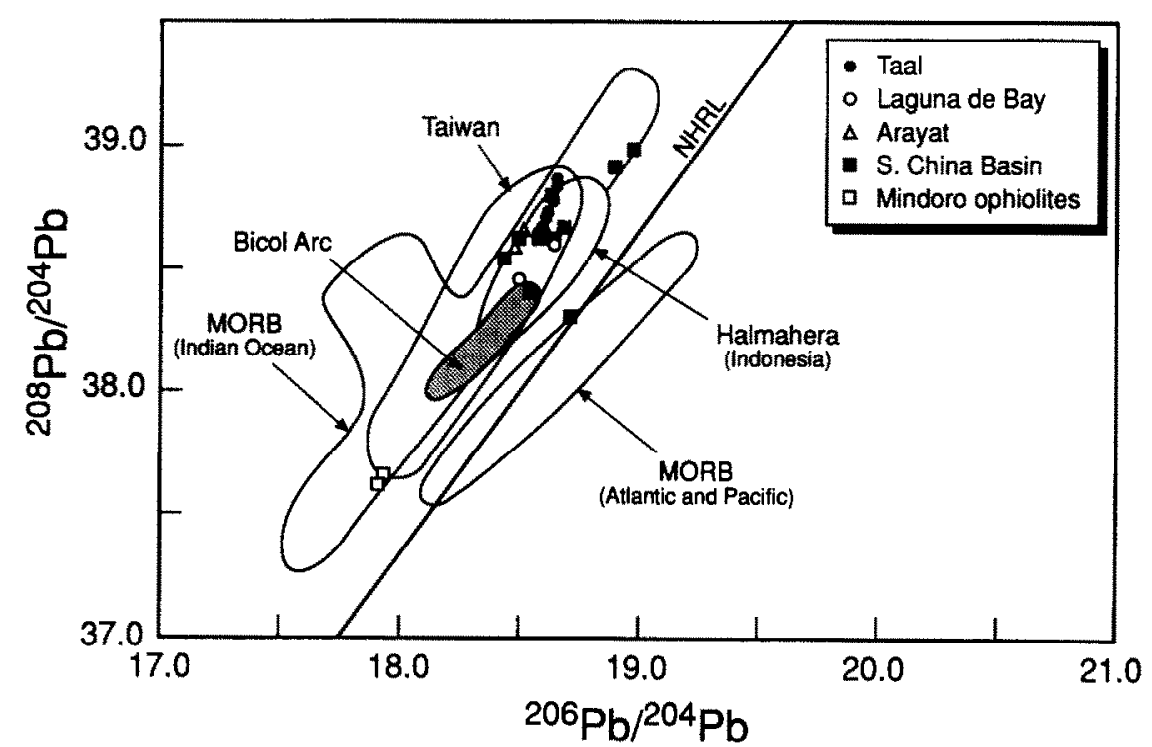

Fig. 4. ${ }^{208} \mathrm{~Pb} /{ }^{204} \mathrm{~Pb}$ versus ${ }^{206} \mathrm{~Pb} /{ }^{204} \mathrm{~Pb}$ covariation diagram for the three Philippine volcanoes studied with various fields for comparison, as described in the caption for Fig. 3. Note that in this covariation space as well, the western Philippine volcanoes are more radiogenic than the volcanoes of the Bicol arc in the eastern Philippines. 


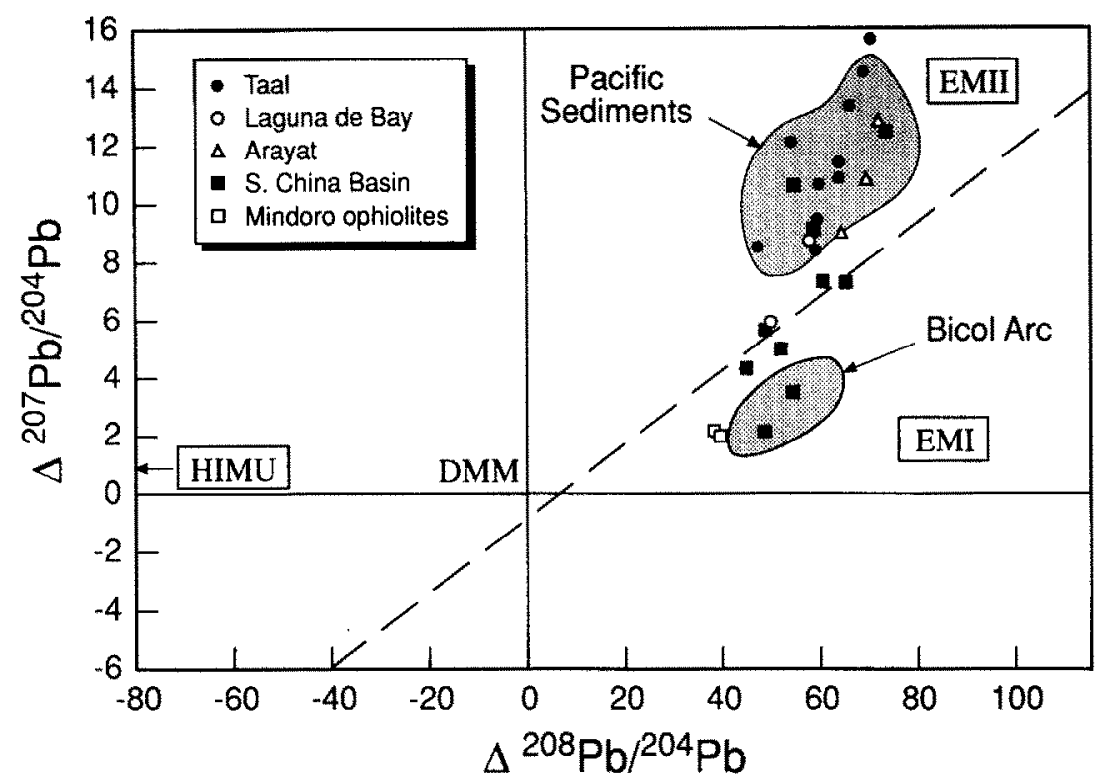

Fig. 5. $\Delta 7 / 4$ versus $\Delta 8 / 4$ diagram comparing the ${ }^{208} \mathrm{~Pb}$ and ${ }^{207} \mathrm{~Pb}$ enrichments of Taal, Laguna de Bay and Arayat volcanoes with enrichments for the Bicol arc in the eastern Philippines and the post-spreading lavas of the South China Sea Basin. The end-members enriched mantle of type I (EM I) and type II (EM II), depleted MORB mantle (DMM), high m (HIMU), the local Mindoro ophiolites and Pacific sediments are also included on the diagram. For the three western Philippine volcanoes, ${ }^{208} \mathrm{~Pb}$ and ${ }^{207} \mathrm{~Pb}$ enrichments are positively correlated. In contrast, the Bicol arc volcanoes and some of the post-spreading lavas in the South China Sea display preferential enrichment in ${ }^{208} \mathrm{~Pb}$ compared to ${ }^{207} \mathrm{~Pb}$. Source materials for the latter appear to have had a time-integrated record of high Th/U. While it is possible that the source of magmas for western Philippine volcanoes also had this elemental signature, the $\mathrm{Pb}$ budget is dominated by components enriched in both ${ }^{208} \mathrm{~Pb}$ and ${ }^{207} \mathrm{~Pb}$ and believed to be largely subducted sediments.

linear trend in the top right-hand quadrant, indicating ${ }^{208} \mathrm{~Pb}$ and ${ }^{207} \mathrm{~Pb}$ enrichments in the lavas relative to northern hemisphere basaltic rocks with similar ${ }^{206} \mathrm{~Pb} /{ }^{204} \mathrm{~Pb}$ values. In contrast to other volcanic centers, in both the BataanMindoro and Bicol arcs, studied by Mukasa et al. (1987), Taal, Laguna de Bay and Arayat have $\Delta^{207} \mathrm{~Pb} /{ }^{204} \mathrm{~Pb}$ and $\Delta^{208} \mathrm{~Pb} /{ }^{204} \mathrm{~Pb}$ values that place them above the best fit regression line for southern hemisphere basaltic rocks as calculated by Hart (1984). ${ }^{207} \mathrm{~Pb}$ enrichment for a given ${ }^{208} \mathrm{~Pb}$ is more pronounced for these samples than in those studied earlier. In this respect, the three volcanoes are similar to some of the post-spreading lavas in the SCSB; the latter, however, include samples which fall below the regression line.

\section{2. ${ }^{143} \mathrm{Nd} /{ }^{144} \mathrm{Nd}-{ }^{87} \mathrm{Sr} /{ }^{86} \mathrm{Sr}$ covariation}

Variations in $\mathrm{Nd}$ and $\mathrm{Sr}$ initial isotopic ratios for the three volcanoes are illustrated in Fig. 6.
For comparison, the diagram includes fields for MORB, OIB and several island arcs, using data from various sources. Data for post-spreading lavas of the SCSB and ophiolitic slivers in Mindoro and Palawan from Tu et al. (1991) are also included. Taal data are remarkably homogeneous, defining a tight cluster toward the lower end of the field for the Izu-Honshu arc in Japan. All three Laguna de Bay samples have initial ${ }^{87} \mathrm{Sr} /{ }^{86} \mathrm{Sr}$ values lower than those of the Taal samples. They also show a wider range in initial ${ }^{143} \mathrm{Nd} /{ }^{144} \mathrm{Nd}$ values, despite the very small sample population. Similarly, the two Arayat samples have initial $\mathrm{Sr}$ ratios lower than those of the Taal samples and are notably different from each other in their initial $\mathrm{Nd}$ ratios. Quite clearly, these three western Philippine volcanoes have $\mathrm{Nd}-\mathrm{Sr}$ isotopic signatures that are discernible from those of the large majority of post-spreading SCSB lavas, the source materials of ophiolitic slivers in Mindoro and Palawan and the Bicol arc (Mukasa 
et al., 1986; Mukasa et al., in review). $\mathrm{Nd}-\mathrm{Sr}$ isotopic data for the Bicol arc fall in the field for the Mariana, New Britain, Aleutian and South Sandwich arcs and are remarkably homogeneous over a wide area.

\section{3. ${ }^{87} \mathrm{Sr} /{ }^{86} \mathrm{Sr}$ versus ${ }^{206} \mathrm{~Pb} /{ }^{204} \mathrm{~Pb}$ covariation}

${ }^{87} \mathrm{Sr} /{ }^{86} \mathrm{Sr}$ versus ${ }^{206} \mathrm{~Pb} /{ }^{204} \mathrm{~Pb}$ values have been plotted together in Fig. 7, which includes the fields for MORB, modern ocean sediments, and

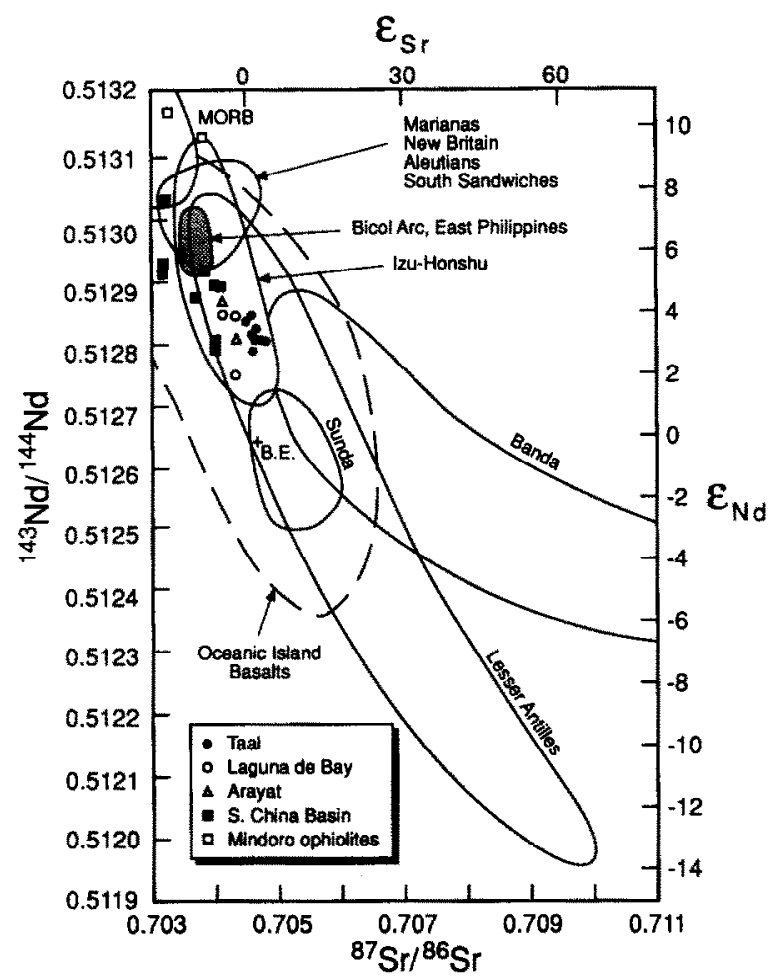

Fig. $6 .{ }^{143} \mathrm{Nd} /{ }^{144} \mathrm{Nd}$ versus ${ }^{87} \mathrm{Sr} /{ }^{86} \mathrm{Sr}$ covariation diagram showing the data for the Philippine volcanoes studied and for the post-spreading lavas of the South China Sea Basin. These are compared to the fields for ocean island basalts (OIB), mid-ocean ridge basalts (MORB) and various arcs (references given in the text). Taal, Laguna de Bay and Arayat volcanoes all have more radiogenic $\mathrm{Sr}$ and less radingenic $\mathrm{Nd}$ than the Bicol arc volcanoes in the eastern Philippines. Their ${ }^{143} \mathrm{Nd} /$ ${ }^{144} \mathrm{Nd}$ values, however, are less radiogenic than bulk earth and yet their ${ }^{147} \mathrm{Sm} /{ }^{144} \mathrm{Nd}$ ratios are lower. This characteristic indicates that the source materials were enriched in light rare earth elements, possibly derived from the subducted components, shortly before melt extraction.

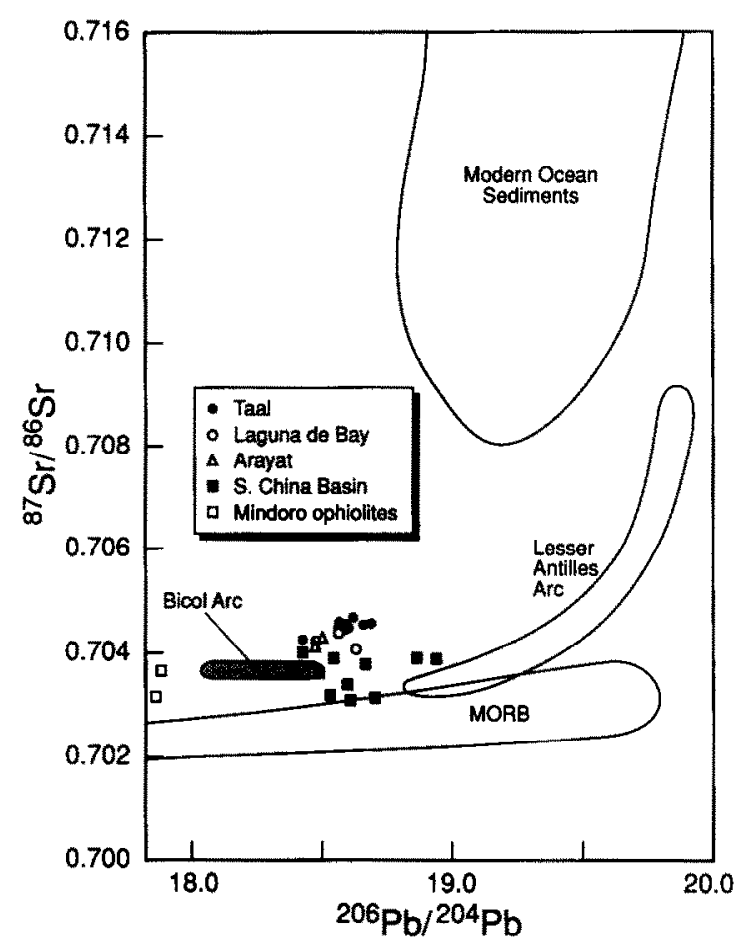

Fig. $7{ }^{87} \mathrm{Sr} /{ }^{86} \mathrm{Sr}$ versus ${ }^{206} \mathrm{~Pb} /{ }^{204} \mathrm{~Pb}$ covariation diagram for Taal, Laguna de Bay and Arayat volcanoes compared to the Bicol arc of the eastern Philippines, post-spreading lavas of the South China Sea Basin (SCSB), MORB, Lesser Antilles arc and modern ocean sediments. Initial ${ }^{87} \mathrm{Sr} /{ }^{86} \mathrm{Sr}$ values for the three western Philippine volcanoes are higher than the values for SCSB lavas of comparable ${ }^{206} \mathrm{~Pb} /{ }^{204} \mathrm{~Pb}$ ratios. However, when compared to their generally high ${ }^{207} \mathrm{~Pb} /{ }^{204} \mathrm{~Pb}$ and ${ }^{208} \mathrm{~Pb} /{ }^{204} \mathrm{~Pb}$ ratios, the western Philippine volcanoes have relatively non-radiogenic $\mathrm{Sr}$.

the Lesser Antilles arc, as well as data points for the Mindoro-Palawan ophiolites and postspreading lavas of the SCSB. The diagram illustrates the point that Taal, Laguna de Bay and Arayat ${ }^{87} \mathrm{Sr} /{ }^{86} \mathrm{Sr}$ values for all but two samples are higher than those of post-spreading lavas in the SCSB, despite the samples having comparable ${ }^{206} \mathrm{~Pb} /{ }^{204} \mathrm{~Pb}$ values. This feature points to $\mathrm{a}$ slight but significant difference in the character of magma sources beneath the two regions. Compared to data for the Lesser Antilles arc (Davidson, 1986), the three Philippine volcanoes have remarkably high $\mathrm{Sr}$ initial ratios for their low ${ }^{206} \mathrm{~Pb} /{ }^{204} \mathrm{~Pb}$. 


\section{4. $\mathrm{Sm} / \mathrm{Nd}$ and $\mathrm{Rb} / \mathrm{Sr}$ for Taal Volcano}

The $\mathrm{Sm}-\mathrm{Nd}$ and $\mathrm{Rb}-\mathrm{Sr}$ concentration data in Table 1 for Taal volcano basalts, basaltic andesites and andesites are plotted as ratios, with the fields for MORB, Iceland, Hawaii and the SCSB post-spreading lavas, in Fig. 8. Rb/Sr values for the two dacite samples are considerably higher than values for the more mafic rock types because of fractional crystallization of plagioclase-bearing assemblages and are therefore excluded from the diagram. Note that the field for Taal would be much smaller if, in order to minimize fractional crystallization effects on the distribution of points, only data for basaltic samples were plotted.

$\mathrm{Sm} / \mathrm{Nd}$ and $\mathrm{Rb} / \mathrm{Sr}$ values for basaltic samples from Taal are not very different from those of the SCSB post-spreading lavas. For the latter, there is no correlation between ratios and compositions, which include nephelinite, alkali olivine basalt, olivine tholeiite and tholeiitic basalt, suggesting that considerable heterogeneities exist, on a regional scale, in the source materials. With the exception of one data point, for a post-spreading olivine tholeiite from the SCSB that has an inexplicably high ratio, $\mathrm{Sm} / \mathrm{Nd}$ values for both Taal and the SCSB post-spreading lavas are lower than the bulk earth value. Conforming with that trace element enrichment history, $\mathrm{Rb} / \mathrm{Sr}$ values for all Taal samples and all but one of the SCSB post-spreading lava samples are higher than the estimated value for bulk earth.

\section{Discussion}

\subsection{Summary of contending petrogenetic models}

Derivation of arc magmas by partial melting of the supra-subduction mantle wedge has supporters (e.g., Arculus, 1981; Stern, 1981; Morris and Hart, 1983), largely because of similarities between ocean island and island arc basalt isotopic and trace element characteristics. In detail, however, important trace element differences, such as

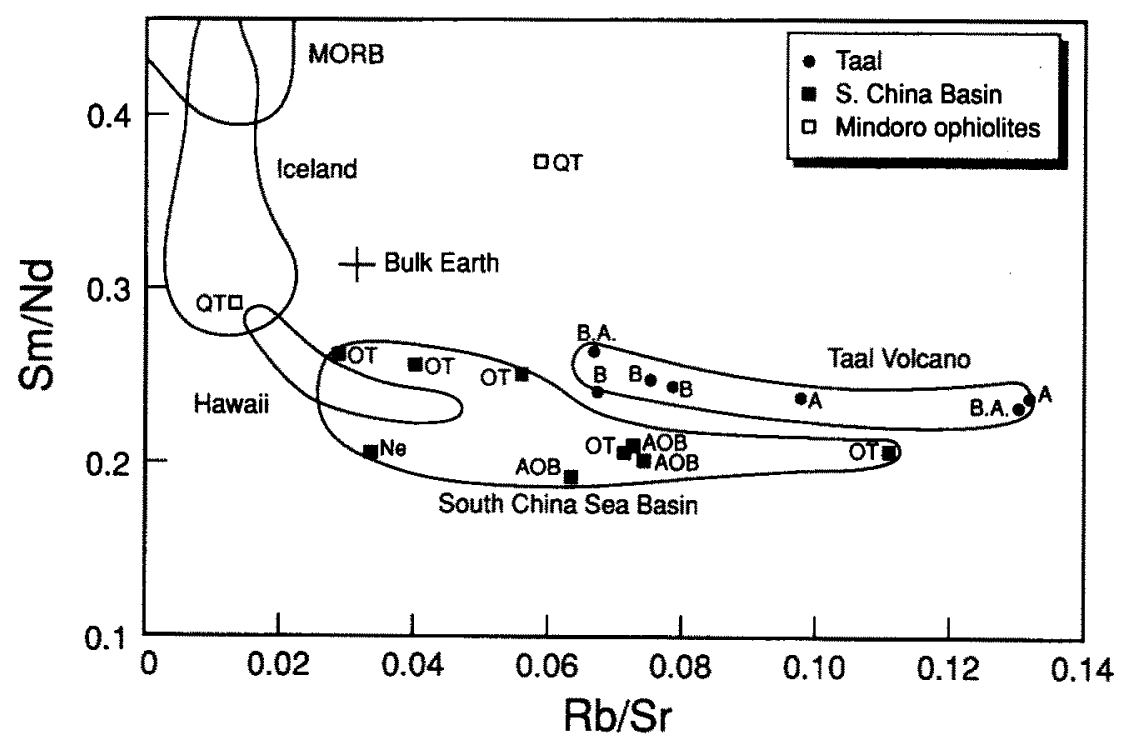

Fig. 8. $\mathrm{Sm} / \mathrm{Nd}$ versus $\mathrm{Rb} / \mathrm{Sr}$ elemental ratios for the samples analyzed for isotopic compositions. $A=$ andesite; $A O B=$ alkali olivine basalt; $B=$ arc basalt; $B A=$ basaltic andesite; $N e=$ nephelinite; $O T=$ olivine tholeiite; $Q T=$ quartz tholeite. The three points with the highest $\mathrm{Rb} / \mathrm{Sr}$ ratios in the field for Taal Volcano, being of basaltic andesite and andesite composition, were probably influenced by fractional crystallization. The basaltic samples in the Taal field have ratios similar to those of the South China Sea Basin post-spreading lavas. Both groups of samples exhibit $\mathrm{Sm} / \mathrm{Nd}$ and $\mathrm{Rb} / \mathrm{Sr}$ ratios indicative of LILE enrichment relative to bulk earth values. 
high Th/La and low HFSE/LREE in arcs are quite prominent (cf. Navon and Stolper, 1987; Kelemen et al., 1990), as are steep trends in $\mathrm{Pb}-\mathrm{Pb}$ space (cf. White and Dupré, 1986; Mukasa et al., 1987).

Wedge and arc crust mixtures have also been considered viable magma sources in a number of studies (e.g., Tilton and Barreiro, 1980; Arculus and Johnson, 1981; Leeman, 1983; Davidson, 1986). This model is particularly appropriate for continental arc lavas that have isotopic signatures resembling those of local ancient sialic crust, yet have mafic varieties not easily explained as pure crustal derivatives. It also seems appropriate for suites of rocks with isotopic patterns (e.g., in $\delta^{18} \mathrm{O}$ versus ${ }^{87} \mathrm{Sr} /{ }^{86} \mathrm{Sr}$ space) more suggestive of upper level crustal contamination than source contamination.

Other studies have recognized that $\mathrm{H}_{2} \mathrm{O}$-rich and/or low-melting subducted slab components are released into the supra-subduction mantle wedge, forming pervasively metasomatized rock mixtures with high potential to produce island arc-type magmas on melting (Kay, 1980; Sun, 1980; Gill, 1981; McCulloch and Perfit, 1981; Mukasa et al., 1987). This model is consistent in many arcs with the observed alkalis/LREE, alkaline earths/LREE and Th/La values. However, devolatilization mechanisms remain poorly constrained and the composition of subducted sediments, which include ferruginous clays and pelagic, hemipelagic, metalliferous and volcaniclastic sediments, are poorly documented. That not withstanding, ${ }^{10} \mathrm{Be}$ studies of arc lavas (Tera et al., 1986; Morris and Tera, 1989; Morris et al., 1990) have provided strong evidence to support the notion that a subducted sediment component contributes to the source materials of arc lavas. With a half-life of only $1.5 \times 10^{6} \mathrm{Ma},{ }^{10} \mathrm{Be}$ decays rapidly in the mantle wedge. Its detection is, therefore, a good indicator of the rapidity with which sedimentary components recycle through subduction zones.

Finally, another model worth considering, particularly for arcs abutting marginal basins, involves the disaggregation by rifting of Andeantype continental margins, resulting in the dispersal of enriched subcontinental lithosphere and its subsequent subduction beneath new arcs (Varne, 1985; Varne and Foden, 1986; Tu et al., 1991). Recognizing eruptive products with enriched subcontinental lithospheric materials of this nature is extremely challenging (e.g., Hawkesworth and Ellam, 1989). At any rate, geochemical comparison of lavas erupted in a marginal basin with those in arc stratovolcanoes beneath which the marginal basin floor subducts is desirable. Considering the rapidity with which subducted sediments are recycled to the mantle wedge, it should be possible, using ${ }^{10} \mathrm{Be}$ and $\mathrm{B}$ systematics (cf. Morris et al., 1990), to distinguish enriched subcontinental lithosphere from recently subducted sedimentary components.

\subsection{Isotopic character of the source materials}

A striking feature of Taal Volcano isotopic compositions is the relative homogeneity of ${ }^{87} \mathrm{Sr}$ / ${ }^{86} \mathrm{Sr}$ and ${ }^{143} \mathrm{Nd} /{ }^{144} \mathrm{Nd}$ (Fig. 6) with high and variable ${ }^{207} \mathrm{~Pb} /{ }^{204} \mathrm{~Pb}$ and ${ }^{208} \mathrm{~Pb} /{ }^{204} \mathrm{~Pb}$ values (Figs. 3 and 4, respectively). On the ${ }^{143} \mathrm{Nd} /{ }^{144} \mathrm{Nd}$ versus ${ }^{87} \mathrm{Sr} /{ }^{86} \mathrm{Sr}$ diagram (Fig. 6), the data form a very small cluster of points near the depleted end of the much larger Lesser Antilles field and within the field for the Izu-Honshu arc of Japan. With points falling well above bulk earth ${ }^{143} \mathrm{Nd} /{ }^{144} \mathrm{Nd}$ values, and having ${ }^{87} \mathrm{Sr} /{ }^{86} \mathrm{Sr}$ values either similar to or less than bulk earth, the source materials appear to have evolved in a long-term depleted environment. The samples are, however, less depleted compared to lavas from the Mariana, New Britain, Aleutian or South Sandwich arcs. In contrast to the homogeneity suggested by $\mathrm{Nd}$ and $\mathrm{Sr}$ ratios, the high-angle $\mathrm{Pb}$-isotopic arrays indicate a more complex heterogeneous source, involving mixing between crustal and MORB-like components, irrespective of the bulk composition or age of the rocks.

A comparison of data for Arayat, Laguna de Bay and Taal shows that isotopic differences between them are small, suggesting that source materials for the three volcanoes were probably similar, despite respective differences in the angle of dip for the subducted slab.

Recent enrichment in LILE of the source is indicated by the decoupling of isotopic and ele- 
mental ratios, whereby low $\mathrm{Sm} / \mathrm{Nd}$, and high $\mathrm{Rb} / \mathrm{Sr}$ values relative to bulk earth (Fig. 8) coincide with a time-integrated $\mathrm{Nd}-\mathrm{Sr}$ isotopic record of depletion. If the inferred enrichment event were old ( $>200 \mathrm{Ma}$ ), there would be more substantial retardation and elevation in the ${ }^{143} \mathrm{Nd} /$ ${ }^{144} \mathrm{Nd}$ and the ${ }^{87} \mathrm{Sr} /{ }^{86} \mathrm{Sr}$ values, respectively. It is unlikely that LILE enrichment reflects small degrees of partial melting as proposed by Defant et al. (1988), inasmuch as this mechanism fails to explain the elevated ${ }^{207} \mathrm{~Pb} /{ }^{204} \mathrm{~Pb}$ values observed. Modification of elemental ratios is best explained by the recent addition of an enriched component, the most likely candidate being subducted marine sediment. This view was rejected by Defant et al. (1988) on the basis of trace element data, which may not be uniquely interpretable. The relatively slight enrichment in the Nd- and Sr-isotopic compositions (cf. the Banda and Lesser Antilles arcs in Fig. 6), may indicate less sedimentary contamination of the southwestern Luzon source, assuming, reasonably, that sediment characteristics are not overly different in the two areas. Assessing when the sedimentary component might have been introduced into the source materials is vitally important in distinguishing whether the sediment involved was subducted since the Eocene inception of the Manila-Negros Trench or was recycled into the subcontinental lithosphere (along the southeast Asia margin in what is now a defunct continental arc) prior to the opening of the SCSB. Presumably, the SCSB source was enriched prior to its opening via disaggregation of the continental arc and, according to this model, west Philippine volcanoes would have acquired the same signature as the result of subduction or delamination during and after collision of the SCSB lithosphere beneath the western margin of the Philippine archipelago. The question of timing is considered below after comparison of elemental and isotopic variations in Philippine and post-spreading SCSB eruptives.

\subsection{Observations based on trace elements}

Trace element data for Taal lavas in Miklius et al. (1991) reflect an increase in the incompatible elements $\mathrm{Ba}, \mathrm{K}, \mathrm{Rb}, \mathrm{Th}$ and $\mathrm{Zr}$ with $\mathrm{SiO}_{2}$, and concomitant decreases in compatible elements such as $\mathrm{Ni}, \mathrm{Cr}$ and $\mathrm{Sr}$. MORB-normalized incompatible element distributions (spidergrams) reflect pronounced 'troughs' for $\mathrm{Ta}, \mathrm{Nb}$ and $\mathrm{Ti}$, characteristic of arc magmas and possibly their sources (Ryerson and Watson, 1987; Kelemen et al., 1990). Despite any isotopic similarities between the post-spreading SCSB and BataanMindoro eruptives, differences in their spidergrams appear to preclude a common source for these magmas.

7.4. Comparison of isotopic and elemental variations between Taal Volcano, the Bicol arc and post-spreading lavas in the SCSB

A comparison of isotopic and trace element data for samples from Taal, the Bicol arc in the eastern Philippines and post-spreading lavas in the SCSB provides some insights into the types of components that might be available in the magma sources for each group. Trace element data for the Bicol arc are only now being acquired by our group and so an interim comparison here must be based on the isotopic data in Mukasa et al. (1986; 1987) and Mukasa et al. (in review).

Of the three areas, the Bicol arc appears to have the simplest isotopic signatures, explicable by magma derivation from source materials with a long, time-integrated record of LILE depletion relative to bulk earth. In Figs. 3 and 4, samples for the Bicol arc fall in the MORB fields (ruled fields), and in Fig. 5, exhibit signs of having been derived from materials with a long history of high $\mathrm{Th} / \mathrm{U}$ values, although not as extreme as MORB and OIB from the Indian Ocean (Dupré and Allègre, 1983; Hart, 1984; 1988).

While their ${ }^{206} \mathrm{~Pb} /{ }^{204} \mathrm{~Pb}$ values are not as low as those of the Bicol arc (Figs. 3, 4 and 7), a large number of the post-spreading lava samples from the SCSB fall in the MORB field, and exhibit Dupal anomaly characteristics as well (Tu et al., 1991). A few samples, however, have elevated ${ }^{207} \mathrm{~Pb} /{ }^{204} \mathrm{~Pb}$ values, placing them outside the MORB field in Fig. 3 and suggesting sediment addition to their source materials sometime prior to magma extraction. With such isotopic heterogeneities, the SCSB group has had a much more 
complex history of LILE depletion and enrichment than has the source material for lavas in the Bicol arc. In having comparatively low $\mathrm{Sr}_{i}$ ratios, falling between 0.70355 and 0.70376 (Figs. 6 and 7), the Bicol arc and post-spreading lavas of the SCSB are similar. However, as already stated, their ${ }^{206} \mathrm{~Pb} /{ }^{204} \mathrm{~Pb}$ values are quite different.

On the other hand, Taal Volcano (and for that matter Laguna de Bay and Arayat volcanoes) have consistently the lowest ${ }^{143} \mathrm{Nd} /{ }^{144} \mathrm{Nd}$, highest ${ }^{87} \mathrm{Sr} /{ }^{86} \mathrm{Sr}$, and most radiogenic $\mathrm{Pb}$ ratios in the three sample groups. For the Taal and SCSB samples, this is despite the fact that $\mathrm{Sm} / \mathrm{Nd}$ and $\mathrm{Rb} / \mathrm{Sr}$ values are similar for all rocks of basaltic composition. If similarity of these elemental ratios was the result of western Philippine volcanoes inheriting enriched Eurasian subcontinental lithosphere, delivered to the archipelago by spreading and subduction associated with opening of the SCSB, then Sr-, Nd- and Pb-isotopic compositions of lavas from the two areas would have been the same. This is not what is observed. Therefore, either the elemental ratios for the two areas were equalized in different and unrelated enrichment events or, following a common enrichment event, west Philippine lava sources were endowed with yet another enriched component, apparently not made available to the post-spreading lavas of the SCSB.

The data require Taal and its neighboring volcanoes to have acquired an LILE enriched component recently. This component is not available to the source regions of the post-spreading lavas in the SCSB or even to the Bicol arc. Recently subducted SCSB sediments, derived largely from young Eurasian crust, comprise the most logical component to introduce the observed LILE enrichment.

Fig. 5 illustrates well the fact that samples from Taal, Laguna de Bay and Arayat volcanoes do not have the classic Dupal-type isotopic anomaly. Elevated ${ }^{208} \mathrm{~Pb} /{ }^{204} \mathrm{~Pb}$ values are accompanied by elevated ${ }^{207} \mathrm{~Pb} /{ }^{204} \mathrm{~Pb}$ values in all samples, indicating unexceptional $\mathrm{Th} / \mathrm{U}$ values in the source. Besides that, ${ }^{87} \mathrm{Sr} /{ }^{86} \mathrm{Sr}$ values for all samples are less than the minimum limit of 0.705 for the Dupal isotopic anomaly. We attribute the positive correlation between ${ }^{208} \mathrm{~Pb} /{ }^{204} \mathrm{~Pb}$ and

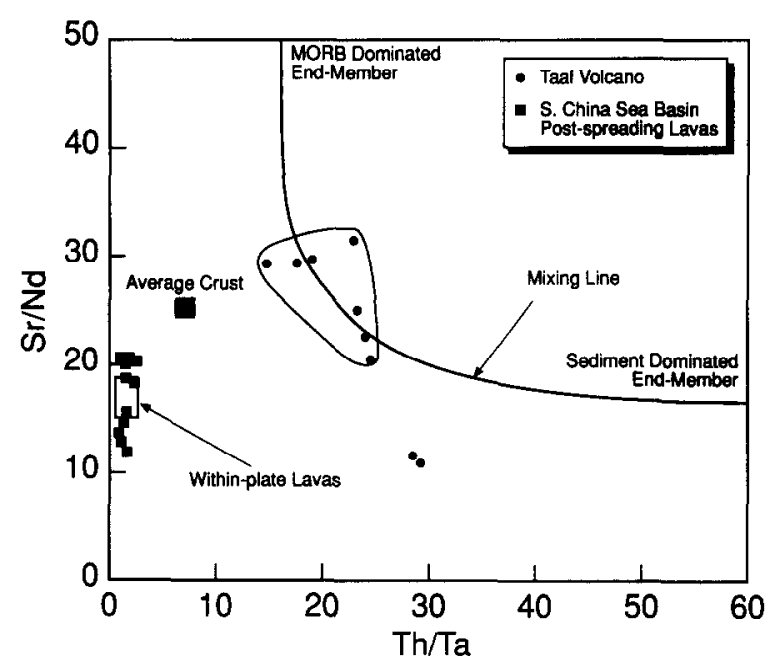

Fig. 9. A comparison of the $\mathrm{Sr} / \mathrm{Nd}$ and $\mathrm{Th} / \mathrm{Ta}$ ratios of Taal Volcano, South China Sea Basin post-spreading lavas, withinplate lavas and average continental crust. The SCSB lavas overlap with the field for within-plate lavas, while the Taal samples fall on a mixing line between MORB and sediment dominated end-members. The two Taal samples off the mixing line are dacitic in composition and might owe their low $\mathrm{Sr} / \mathrm{Nd}$ to plagioclase fractional crystallization.

${ }^{207} \mathrm{~Pb} /{ }^{204} \mathrm{~Pb}$ values also to involvement of recently subducted SCSB sediments at the source.

Varied but small degrees of partial melting, long-held source heterogeneities and the introduction of a sedimentary component into the supra-subduction mantle wedge are the processes that determine the trace element inventories of derivative melts prior to any fractionation effects. Fig. 9, a plot of $\mathrm{Sr} / \mathrm{Nd}$ versus $\mathrm{Th} / \mathrm{Ta}$ for SCSB post-spreading lavas (solid squares) and Taal Volcano (circles), highlights our view that different sources or magma evolution mechanisms have prevailed in the two areas. For comparison, notice the location of average crust (Taylor and McLennan, 1985), within-plate lavas and fresh MORB glass (Hofmann, 1988), as well as the mixing line between altered MORB and sediment-dominated end-members, first modelled by Rogers et al. (1985). If the two dacite samples from Taal (the two points below the mixing trend) are excluded to minimize the effects of plagioclase fractional crystallization on the observed Sr/Nd values, then Taal samples lie reasonably 
close to the mixing line between altered MORB and sediment-dominated end-members. In contrast, SCSB post-spreading lavas have much lower $\mathrm{Th} / \mathrm{Ta}$ values and are essentially indistinguishable from within-plate lavas and fresh MORB glass. We view this difference as another good indication that magma sources of the three western Philippine volcanoes studied have been permeated with an LILE-enriched component that appears to be absent in SCSB post-spreading lavas. Subducted, continentally derived sediments explain satisfactorily the observed high $\mathrm{Th} / \mathrm{Ta}$ values in Taal Volcano and other volcanoes in the western Philippines.

\section{Conclusions}

From the above the following conclusions can be drawn:

(1) The source materials of lavas from Taal and other western Philippine volcanoes have undergone recent enrichment in LILE, as indicated by the decoupling of isotopic and elemental ratios. Their derivative magmas have low $\mathrm{Sm} / \mathrm{Nd}$ relative to bulk earth, and yet their ${ }^{143} \mathrm{Nd} /{ }^{144} \mathrm{Nd}$ values exhibit a time-integrated record of depletion. $\mathrm{Rb} / \mathrm{Sr}$ values of the magmas are also considerably higher than the bulk earth value, whereas corresponding ${ }^{87} \mathrm{Sr} /{ }^{86} \mathrm{Sr}$ values are either less than, or are close to, the estimated bulk earth ratio.

(2) LILE enrichment in lavas from Taal, Laguna de Bay and Arayat volcanoes cannot be entirely due to small degrees of partial melting. The trace element enrichment is accompanied by substantial elevations in radiogenic $\mathrm{Pb}$, a feature best explained by the introduction of subducted, continentally derived sediments.

(3) Lavas frorn the three western Philippine volcanoes studied and from the post-spreading group in the South China Sea have some small, but nevertheless important, differences in both elemental and isotopic ratios, requiring different source materials. Although $\mathrm{Sm} / \mathrm{Nd}$ and $\mathrm{Rb} / \mathrm{Sr}$ values for basaltic rocks from the two areas are virtually the same, western Philippine volcanoes have consistently higher ${ }^{87} \mathrm{Sr} /{ }^{86} \mathrm{Sr}, \mathrm{Sr} / \mathrm{Nd}$, and
$\mathrm{Th} / \mathrm{Ta}$ and, for the most part, lower ${ }^{143} \mathrm{Nd} /{ }^{144} \mathrm{Nd}$ values. In addition, all but one of the samples from the three volcanoes analyzed fall above the MORB field, whereas the majority of the postspreading lavas from the SCSB fall within it on both $\mathrm{Pb}$-covariation diagrams.

(4) The sedimentary component that influenced the trace element and isotopic character of lavas from the three western Philippine volcanoes is not available to Bicol arc volcanoes lining the eastern margin of the archipelago. This is reflected in the latter having comparatively higher ${ }^{143} \mathrm{Nd} /{ }^{144} \mathrm{Nd}$ and lower ${ }^{87} \mathrm{Sr} /{ }^{86} \mathrm{Sr}$ values, as well as less radiogenic common $\mathrm{Pb}$ with Dupal-type isotope characteristics. The most logical enriched component available to the Manila-Negros subduction zone, which is completely missing on the eastcrn side of the archipelago, is South China Sea basin sediments, derived largely from Eurasia.

\section{Acknowledgments}

We are indebted to personnel at the Philippine Institute of Volcanology and Seismology, particularly Director Ray Punongbayan, for assistance with logistics in the field. Research funding for this study came chiefly from National Science Foundation grants EAR-8721416 (M.F.J.F) and EAR-8996316 (S.B.M.). Thoughtful reviews have been provided by Pat Castillo, John Encarnación and Robert Stern, to whom we are most grateful.

\section{References}

Arculus, R.J., 1981. Island arc magmatism in relation to the evolution of the crust and mantle. Tectonophysics, 75: $113-133$.

Arculus, R.J. and Johnson, R.W., 1981. Island arc magma sources: A geochemical assessment of the roles of slab-derived components and crustal contamination. Geochem. J., 15: $109-133$.

Balce, G.R., Crispin, O.A., Samaniego, S.M. and Miranda, F.E., 1981. Metallogenesis in the Philippines. Geol. Surv. Jpn. Rep., 261: 125-148.

Cardwell, R.K., Isacks, B.L. and Karig, D.E., 1980. The spatial distribution of earthquakes, focal mechanism solutions, and subducted lithosphere in the Philippine and 
northeastern Indonesian islands. In: D.E. Hayes (Editor), The Tectonic and Geologic Evolution of Southeast Asian Seas and Islands. Am. Geophys. Union Geophys. Monogr., 23: $1-35$.

Cohen, R.S. and O'Nions, R.K., 1982. The lead, neodymium and strontium isotopic structure of ocean ridge basalts. $J$. Petrol., 23: 299-324.

Cruz, J. and Umbal, J., 1983. Volcanology and Philippine volcanism: some issues and problems. Phil. J. Volcanol., 1: 3-10.

Davidson, J.P., 1986. Isotopic and trace element constraints on the petrogenesis of subduction-related lavas from Martinique, Lesser Antilles. J. Geophys. Res., 91: 5943-5962.

De Boer, J.Z, Odom, L.A., Ragland, P.C., Snider, F.C. and Tilford, N.R., 1980. The Bataan orogene: eastward subduction, tectonic rotations, and volcanism in the western Pacific (Philippines). Tectonophysics, 67: 251-282.

Defant, M.J., De Boer, J.Z. and Oles, D., 1988. The western Central Luzon volcanic arc, the Philippines: two arcs divided by rifting? Tectonophysics, $145: 305-317$.

Defant, M.J., Jacques, D., Maury, R.C., De Boer, J.Z. and Joron, J.-L., 1989. Geochemistry and tectonic setting of the Luzon arc, Philippines. Geol. Soc. Am. Bull., 101: $663-672$.

Divis, A.F., 1980. The petrology and tectonics of recent volcanism in the Central Philippine Islands. In: D.E. Hayes (Editor), The Tectonic and Geologic Evolution of Southeast Asian Seas and Islands. Am. Geophys. Union Geophys. Monogr., 23: 127-144.

Dupré, B. and Allègre, C.J., 1983. $\mathrm{Pb}-\mathrm{Sr}$ isotopic variations in Indian Ocean basalts and mixing phenomena. Nature, 303 : $142-146$.

Förster, H., Oles, D., Knittel, U., Defant, M.J. and Torres, R.C., 1990. The Macolod Corridor: A rift crossing the Philippine island arc. Tectonophysics, 183: 265-271.

Fuller, M.D., McCabe, R., Williams, I., Almasco, J., Encina, R.Y., Zanoria, A.S. and Wolfe, J.A., 1983. Paleomagnetism of Luzon. In: D.E. Hayes (Editor), The Tectonic and Geologic Evolution of Southeast Asian Seas and Islands, Part 2. Am. Geophys. Union Geophys. Monogr., 27: 79-94.

Gill, J.B., 1981. Orogenic Andesites and Plate Tectonics. Springer, Berlin, $390 \mathrm{pp}$.

Hamburger, M.W., Cardwell, R.K. and Isacks, B.L., 1983. Seismotectonics of the Northern Philippine Island Arc. In: D.E. Hayes (Editor), The Tectonic and Geologic Evolution of Southeast Asian Seas and Islands, Part 2. Am. Geophys. Union Geophys. Monogr., 27: 1-22.

Hamelin, B. and Allègre, C.J., 1985. Large-scale regional units in the depleted upper mantle revealed by an isotope study of the south-west Indian Ridge. Nature, 315: 196198.

Hamelin, B., Dupré, B. and Allègre, C.J., 1984. Leadstrontium isotopic variations along the East Pacific Rise and the Mid-Atlantic ridge: a comparative study. Earth Planet. Sci. Lett., 67: 340-350.

Hamelin, B., Dupré, B. and Allègre, C.J., 1986. $\mathrm{Pb}-\mathrm{Sr}-\mathrm{Nd}$ isotopic data of Indian Ocean Ridges: new evidence of large-scale mapping of mantle heterogeneities. Earth Planet. Sci. Lett., 76: 288-298.

Hamilton, W.B., 1979. Tectonics of the Indonesian region. US Geol. Surv. Prof. Pap. 1078: 1-345.

Hart, S.R., 1984. A large-scale isotopic anomaly in the southern hemisphere. Nature, 309: 752-757.

Hart, S.R., 1988. Heterogeneous mantle domains: Signatures, genesis and mixing chronologies. Earth Planet. Sci. Lett., 90: 273-296.

Hashimoto, W., 1981. Geologic development of the Philippines. Geol. Paleontol. Southeast Asia, 22: 83-170.

Hawkesworth, C.J. and Ellam, R., 1989. Chemical fluxes and wedge replenishment rates along recent destructive plate margins. Geology, 17: 46-49.

Hayes, D.E. and Lewis, S.D., 1984. A geophysical study of the Manila Trench, Luzon, Philippines 1. Crustal structure, gravity and regional tectonic evolution. J. Geophys. Res., 89: 9171-9195.

Hickey-Vargas, R., 1991. Isotope characteristics of submarine lavas from the Philippine Sea: implications for the origin of arc and basin magmas of the Philippine tectonic plate. Earth Planet. Sci. Lett., 107: 290-304.

Hofmann, A.W., 1988. Chemical differentiation of the Earth: the relationship between mantle, continental crust, and oceanic crust. Earth Planet. Sci. Lett., 90: 297-314.

Hsii, 1., 1972. Magnetic properties of igneous rocks in the northern Philippines. PhD Diss., Washington Univ., St. Louis, MO, 165pp.

Karig, D.E., 1983. Accreted terranes in the northern part of the Philippine Archipelago. Tectonics, 2: 211-236.

Karig, D.E., Sarewitz, D.R. and Haeck, G.D., 1986. Role of strike-slip faulting in the evolution of allochthonous terranes in the Philippines. Geology, 14: 852-855.

Kay, R.W., 1980. Volcanic arc magmas: Implications for a melting-mixing model for element recycling in the crustupper mantle system. J. Geol., 88: 497-522.

Kelemen, P.B., Johnson, K.T.M., Kinzler, R.J. and Irving, A.J., 1990. High-field-strength element depletions in arc basalts due to mantle-magma interaction. Nature, 345: 521-524.

Knittel, U., Defant, M.J. and Raczek, I., 1988. Recent enrichment in the source region of arc magmas from Luzon island, the Philippines: Sr and Nd isotopic evidence. Geology, 16: 73-76.

Leeman, W.P., 1983. The influence of crustal structure on compositions of subduction-related magmas. J. Volcanol. Geotherm. Res., 18: 561-588.

Mahoney, J.J., Natland, J.H., White, W.M., Poreda, R., Bloomer, S.H., Fisher, R.L. and Baxter, A.N., 1989. Isotopic and geochemical provinces of the Western Indian Ocean spreading centers. J. Geophys. Res., 94: 4033-4052.

McCabe, R., Almasco, J. and Yumul, G., 1985. Terranes of the Central Philippines. In: D. Howell (Editor), Tectonostratigraphic terranes of the circum-Pacific region. Coun. Energy Miner. Resour. Earth Sci. Ser, 1: 421-435.

McCulloch, M.T. and Perfit, M.R., 1981. ${ }^{143} \mathrm{Nd} /{ }^{144} \mathrm{Nd},{ }^{87} \mathrm{Sr} /$ 
${ }^{86} \mathrm{Sr}$ and trace element constraints on the petrogenesis of Aleutian island arc magmas. Earth Planet. Sci. Lett., 56: $167-179$.

Miklius, A., Flower, M.F.J., Huijsmans, J.P.P., Mukasa, S.B. and Castillo, P., 1991. Geochemistry of lavas from Taal Volcano, southwestern Luzon, Philippines: Evidence for multiple magma supply systems and mantle source heterogeneity. J. Petrol., 32: 593-627.

Morris, J.D. and Hart, S.R., 1983. Isotopic and incompatible element constraints on the genesis of island arc volcanics from Cold Bay and Amak Island, Aleutians, and implications for mantle structure. Geochim. Cosmochim. Acta, 47: $2015-2030$.

Morris, J. and Tera, F, 1989. ${ }^{10} \mathrm{Be}$ and ${ }^{9} \mathrm{Be}$ in mineral separates and whole rocks from volcanic arcs: Implications for sediment subduction. Geochim. Cosmochim. Acta, 53: 3197-3206.

Morris, J.D., Jezek, P.A., Hart, S.R. and Gill, J.B., 1983. The Halmahera island arc, Molucca Sea collision zone, Indonesia: a geochemical survey. In: D.E. Hayes (Editor), The Tectonic and Geologic Evolution of Southeast Asian Seas and Islands, Part 2. Am. Geophys. Union Geophys. Monogr., 27: 373-387.

Morris, J.D., Leeman, W.P. and Tera, F, 1990. The subducted component in island arc lavas: constraints from $\mathrm{Be}$ isotopes and B-Be systematics. Nature, 344: 31-36.

Mukasa, S.B., McCabe, R., Gill, J.B. and Newhall, C., 1986. Philippine island arc Pb-isotopic compositions: the Dupal anomaly in a northern hemisphere island arc? EOS, Trans. Am. Geophys. Union, 67: 1273.

Mukasa, S.B., McCabe, R. and Gill, J.B., 1987. Pb-isotopic compositions of volcanic rocks in the West and East Philippine island arcs: presence of the Dupal isotopic anomaly. Earth Planet. Sci. Lett., 84: 153-164.

Mukasa, S.B., Flower, M.F.J. and Arcilla, C., Differences in the isotopic and trace element compositions of volcanic chains associated with the oppositely-dipping Philippine subduction zones: constraints on the character of the source components. Geochim. Cosmochim. Acta (in review.).

Navon, O. and Stolper, E., 1987. Geochemical consequences of melt percolation: the upper mantle as a chromatographic column. J. Geol., 95: 285-307.

Rangin, C., Stephan, J.F., Blanchet, R., Baladad, D., Bouysee, P., Chen, M.P. and Chotin, P., 1988. Seabeam survey at the southern end of the Manila trench. Tectonophysics, 146: $261-278$.

Rogers, N.W., Hawkesworth, C.J., Parker, R.J. and Marsh, IS., 1985. The geochemistry of potassic lavas from Vulsini, central Italy and implications for mantle enrichment processes beneath the Roman region. Contib. Mineral. Petrol, 90: 244-257.

Ru, K. and Pigott, J.D., 1986. Episodic rifting and subsidence in the South China Sea. Am. Assoc. Pet. Geol. Bull., 70: 1136-1155.

Ryerson, F.J. and Watson, E.B., 1987. Rutile saturation in magmas: Implications for $\mathrm{Ti}-\mathrm{Nb}-\mathrm{Ta}$ depletion in islandarc basalts. Earth Planet. Sci. Lett., 86: 225-239.
Stern, R.J., 1981. A common mantle source for western Pacific island arc and "hot spot" magmas-Implications for layering in the upper mantle. Carnegie Inst. Year Book, Washington, 81: 455-462.

Sun, S.-s., 1980. Lead isotopic study of young volcanic rocks from mid-ocean ridges, oceanic islands and island arcs. Philos. Trans. R. Soc. London, Ser. A, 297: 409-455.

Sun, S.-s., Tatsumoto, M. and Schilling, J.G., 1975. Mantle plume mixing along the Reykjanes ridge axis: lead isotope evidence. Science, 190: 143.

Tapponnier, P., Peltzer, G. and Armijo, R., 1986. On the mechanics of the collision between India and Asia. In: M.P. Coward and A.C. Reis (Editors), Collision Tectonics. Geol. Soc. London Spec. Publ., 19: 115-157.

Tatsumoto, M. and Nakamura, Y., 1991. DUPAL anomaly in the Sea of Japan: $\mathrm{Pb}, \mathrm{Nd}$ and $\mathrm{Sr}$ isotopic variations at the eastern Eurasian continental margin. Geochim. Cosmochim. Acta, 55: 3697-3708

Taylor, B. and Hayes, D.E., 1983, Origin and history of the South China Sea Basin. In: D.E. Hayes (Editor), The Tectonic and Geologic Evolution of Southeast Asian Seas and Islands, Part 2. Am. Geophys. Union Geophys. Monogr., 27: 23-56.

Taylor, S.R., and McLennan, S.M., 1985. The Continental Crust: its Composition and Evolution. Blackwell, Oxford, UK, 312pp.

Tera, F., Brown, L., Morris, J., Sacks, I.S., Klein, J, and Middleton, R., 1986. Sediment incorporation in island-arc magmas: inferences from ${ }^{10} \mathrm{Be}$. Geochim. Cosmochim. Acta, 50: 535-550.

Tilton, G.R. and Barreiro, B.A., 1980. Origin of lead in Andean calc-alkaline lavas, southern Peru. Science, 210: 1245-1247.

Tu, K., Flower, M.F.J., Carlson, R.W., Zhang, M. and Xie, G., 1991. Sr, Nd, and $\mathrm{Pb}$ isotopic compositions of Hainan basalts (south China): Implications for a subcontinental lithosphere Dupal source. Geology, 19:567-569.

Varne, R., 1985. Ancient subcontincntal mantle: a source of K-rich orogenic volcanics. Geology, 13: 405-408.

Varne, R. and Foden, J.D., 1986. Geochemical and isotopic systematics of Eastern Sunda arc volcanics: implications for mantle sources and mantle mixing processes. In: F.C. Wezel (Editor), Origin of Arcs. Elsevier, Amsterdam, pp. 159-189.

Vidal, $\mathrm{Ph}$. and Clauer, N., 1981. Pb and $\mathrm{Sr}$ isotopic systematics of some basalts and sulfides from the Fast Pacific Rise at $21^{\circ} \mathrm{N}$ (project RITA). Earth Planet. Sci. Lett., 55: $237-$ 246.

White, W.M. and Dupré, B., 1986. Sediment subduction and magma genesis in the Lesser Antilles: isotopic and trace element constraints. J. Geophys. Res., 91: 5927-5941.

Wolfe, J.A. and Self, S., 1983. Structural lineaments and Neogene volcanism in southwestern Luzon. In: D.E. Hayes (Editor), The Tectonic and Geologic Evolution of Southeast Asian Seas and Islands, Part 2. Am. Geophys. Union Geophys. Monogr., 27: 157-172. 